Journal of Science Education Research

Journal homepage: www.journal.uny.ac.id/jser

JSER

\title{
The effect of virtual instrument system laboratory to enhance technological literacy and problem-solving skills among junior high school students
}

\author{
Supahar $^{1 *}$, Eko Widodo ${ }^{2}$ \\ ${ }^{1}$ Study Program of Physics Education, Faculty of Mathematics and Natural Sciences, Universitas Negeri Yogyakarta \\ ${ }^{2}$ Study Program of Science Education, Faculty of Mathematics and Natural Sciences, Universitas Negeri Yogyakarta \\ Corresponding Author. Email: $\underline{\text { supahar@uny.ac.id }}$
}

Keywords:
one or more
important, specific,
or representative
word(s) or
phrase(s)

Keywords:

one or more

important, specific,

word(s) or

phrase(s)

\begin{abstract}
This study aims at analyzing the effect of the Virtual Instrument System Laboratory (Vis-Lab) to enhance technological literacy and problem-solving skills among junior high school students. This type of research can be categorized as Quasi-experimental research with Nonequivalent Control Group Design. The subjects of this study were the seventh-grade students in one of the junior high schools in Sleman Regency, Yogyakarta. The research instrument consisted of pretest and posttest on technological literacy and problem-solving skills. The data analysis technique used N-Gain analysis, prerequisite test, hypothesis testing with MANOVA, and effect size. Based on the MANOVA test, the Sig. value of $0,000<\alpha(0.05)$ indicated that there was a gap in the students' technological literacy and problem-solving skills between the control and the experimental class. The use of VIS-Lab learning media enhanced the ability of technological literacy by $9.0 \%$ for the experimental class and $2.1 \%$ for the control class respectively. Meanwhile, the effective contribution to the use of VIS-Lab learning media was $36.5 \%$ for the experimental class and $4.73 \%$ for the control class. It means that the use of VIS-Lab learning media contribute effectively to improving the ability of technological literacy and problem-solving.
\end{abstract}

C2021 JSER. Universitas Negeri Yogyakarta

\section{INTRODUCTION}

Virtual Instrument System Laboratory (VIS-LAB) is a series of interactive multimedia software for laboratory learning. It is operated by a computer and can simulate activities as if the user is in a real laboratory setting. VIS-LAB can bring the actual laboratory practicum within a computer (Dyrberg, Treusch, \& Wiegand, 2017: 358374). VIS-Lab media can also be used to convey information, obtain feedback, improve motivation, and concentration, thereby to enhance students' learning outcomes (Funk, Kellner, \& Share, 2016: 3-7).

As a practicum simulation that is identical to an actual setting, VIS-LAB can elevate the students' understanding by providing independent learning processes (Herga, Čagran, \& Dinevski, 2016). It has also been proven that interactive learning through VIS-LAB can help students to solve abstract learning concepts by allowing them to construct and understand difficult concepts, so they are more active in their learning process 
(Climent-Bellido, Martínez-Jiménez, PontesPedrajas, \& Polo, 2003).

VIS-Lab learning has been listed as one of the prominent elements in the current education system (Winkelmann et al., 2017: 115) that emphasize technological advances in learning implementation (Bautista \& Boone, 2015). It is consistent with the needs of technological awareness among students (Ahmed, 2014: 355-371). Besides, teachers are also demanded to improve their technological literacy and to make IT based-learning media (McGarr, 2020: 1-11). It makes VIS-Lab effective to improve technology literacy and problem-solving skills. Technological literacy is a way of thinking on how technology to be used as a tool that can be used to solve problems. It also refers to one's ability to work independently or in groups that are effective, responsible, and appropriate in using technology as a tool to obtain, manage, integrate, evaluate, create and communicate information.

According to Martin (2006:155), digital literacy is the awareness, attitude and ability of individuals to appropriately use digital tools and facilities them to identify, access, manage, integrate, evaluate, analyze and synthesize digital resources, construct new knowledge, create media, and communicate with others, in the context of specific life situations, to enable constructive social action; and to reflect upon this process. Similarly, Erstad (2008) proposes the term of technology literacy as a set of skills, knowledge, and attitudes for media use dealing with the challenges of learning societies.

Gilster (1997) highlights the importance to enhance technological awareness and information evaluation instead of technical skills. UNESCO (United Nations Education, Scientific and Cultural Organization) strives to bring technology literacy to students throughout the world by ensuring teachers use technology in every aspect of their teaching. The more familiar the students with technology in the learning process, the more they will be ready to use it to improve their lives (2019).

Another ability that develops with the use of Vis-Lab is problem-solving skills (McGarr, 2020: 1-11) Problem solving designed in VisLab is a complex cognitive skill, and perhaps, the most intelligent ability possessed by humans (Chi \& Glaser in Matlin, 1989). Gagne (in Foshay \& Kirkley, 2003) defines problemsolving as one's effort to synthesize knowledge, rules, concepts, schemes, or experiences that are already existed with the conditions that they face to find solutions. Mayer (in Foshay \& Kirkley, 2003) explains that problem-solving is required to find the relationship between the experiences (schemes) with the problems encountered to do something to find an appropriate solution. Meanwhile, according to Matlin (1989), problem-solving is needed when an individual has the desire to achieve a certain goal.

By using Vis-Lab, problem-solving is not only considered as an activity to solve problems but also complex activity involving cognitive, behavior, and attitude (Foshay \& Kirkley, 2003). NCTM (2000) suggests problem-solving as an activity that requires critical and creative thinking due to the demand to find the right strategy, or even alternative strategies, in solving the problem.

Based on the background of this problem, it can be concluded that problem-solving skills are a direct impact of the Vis-Lab application in science learning, while technology literacy is the impact of the utilization of digital technology in learning.

\section{RESEARCH METHOD}

This study employed Quasi-Experiment research in one state junior high school in Sleman Regency, Yogyakarta. The population included all seventh-grade students' in the academic year of 2019/2020 totaling 237 students which was divided into seven classes. The research sample was selected using a purposive sampling technique with two classes, class VII D as a control class and VII $\mathrm{E}$ as an experimental class. Data collection in this 
Supahar, Eko Widodo/ JSER 2021, 5(2), 36

research was carried out in two stages. The first data was in the form of descriptive qualitative data from the trial process of VIS-Lab application on mechanical wave material. The second was quantitative data in the form of test results on the effect of the VIS-Lab application to improve students' technological literacy and problemsolving skills. The data were collected using test and non-test techniques. The non-test techniques were used to observe the learning implementation using VIS-Lab.

The non-test data were also obtained from the questionnaire results about the practicality of VISLab in Science learning, while the testing data obtained from the measurement of students' technological literacy and problem-solving skills. The data on problem-solving skills were obtained from pre-test and post-test on the experimental classes that were using VIS-Lab and the control classes that were implementing realistic practicum.

The study used a non-equivalent control group design as presented in Table 1 below.

Table 1. Research design

\begin{tabular}{lccc}
\hline \multicolumn{1}{c}{ Group } & Pretest & $\begin{array}{c}\text { Treatment } \\
(\mathrm{X})\end{array}$ & Posttest \\
\hline Group & O1A, & $\mathrm{X} 1$ & O3A, \\
Experiment & O1B & & O3B \\
Group & O2A, & X2 & O4A, \\
Control & O2B & & O4B \\
\hline
\end{tabular}

\section{Explanation:}

$\mathrm{X} 1=$ Treatment with VIS-Lab learning

$\mathrm{X} 2=$ Treatment with realistic practicum

$\mathrm{O} 1 \mathrm{~A}=$ Pretest of technological literacy

$\mathrm{O} 2 \mathrm{~B}=$ Pretest of problem-solving

$\mathrm{O} 3 \mathrm{~A}=$ Posttest of technological literacy

$\mathrm{O} 4 \mathrm{~B}=$ Posttest of problem solving

The collected data included students' technological literacy and problem-solving skills which were obtained through the pretest and the posttest. It was followed by the $\mathrm{N}$-Gain score calculation using the following formula.

$$
<g>=\frac{<\% \text { post }>-<\% \text { pre }>}{100 \%-<\% \text { pre }>}
$$

\section{Explanation:}

$$
\langle\mathrm{g}\rangle \quad=\text { average normalized gain }
$$

$<\%$ post $>\quad=$ percentage of average Post-test

value

$\langle \%$ pre $>\quad=$ percentage average Pre-test

value

$100 \%=$ maximum score

The results of the N-Gain calculation are interpreted with the following categorization.

Table 2. N-Gain Interpretation

\begin{tabular}{cl}
\hline Score $\langle\mathrm{g}\rangle$ & Interpretation \\
\hline$-1.00 \leq g<0.00$ & Declining \\
$\mathrm{g}=0.00$ & No declining \\
$0.7<g<1$ & High \\
$0.3 \leq g \leq 0.7$ & Moderate \\
$0<g<0.3$ & Low \\
\hline
\end{tabular}

After that, the N-Gain score in the prerequisite tests included tests of normality (Kolmogorov Smirnov) and homogeneity (Levene's Test of Equality of Error Variances). The significance of the improvement in the students' technology literacy and problem-solving was tested using Two Multivariate Analysis of Variance (MANOVA) Groups. The media of VIS-Lab as an independent variable, while the ability of Technology Literacy and problem solving as the dependent variable. The normality test and homogeneity test as a prerequisite test were carried out before the MANOVA test. Hypothesis testing through MANOVA analysis of the N-Gain score and also the effect size was calculated using the following formula.

$$
d=\frac{\bar{x}_{1}-\bar{x}_{2}}{S_{g a b}}
$$

with

$S_{g a b}=\sqrt{\frac{\left(n_{1}-1\right) S_{1}^{2}+\left(n_{2}-1\right) S_{2}^{2}}{n_{1}+n_{2}-2}}$

\section{Explanation:}

$\mathrm{d}=$ the amount of effect size

$x_{1}=$ average of experiment class

$\bar{x}_{2}=$ average of control class

$S_{g a b}=$ standard deviation combination

$n_{1}=$ number of students in experiment class 
$n_{2}=$ number of students in control class

$S_{1}^{2}=$ experimental class variance

$S_{2}^{2}=$ pcontrol class variance

The interpretation of Effect Size can be explained in Table 3 below.

Table 3. Effect Size Interpretation

\begin{tabular}{cc}
\hline Effect Size & Category \\
\hline $0-0.5$ & Low \\
$0.6-0.8$ & Quite High \\
$0.9-3$ & High \\
\hline
\end{tabular}

Source: Becker, 2000

The analysis of size effect was used to find out the extent to which the escalation of students' technological literacy and problem-solving skills between the VIS-Lab learning classes and the classes without VIS-Lab learning. The extent of the improvement in the students' technological literacy and problem-solving was analyzed by reviewing the value of Partial Eta Squared.

\section{RESULTS AND DISCUSSION}

In this study, researchers developed and tested a Virtual Science Laboratory for junior high school students in several provinces in Indonesia. In this Virtual Laboratory, there are 3 practicum groups, namely; Physics Practicum (Measurement Tool and Pascal's Law), Biology Practicum (Observation with
Microscope, Variety of Bread Mushrooms), and Chemistry Practicum (Acid-Base Simulation, Acid-Base Indicator). All of these animation programs have been tested by involving science teachers in Indonesia so that they can use these Virtual Labs services in their learning activities. This virtual laboratory program is very helpful because it was implemented during the Covid-19 Pandemic, so that learning is entirely carried out online. Teachers can take advantage of Virtual Labs both using Android and Laptop platforms to support learning that is relevant to their learning objectives. This is very useful, especially in the event of a pandemic of certain diseases such as 2020. Teachers cannot do practicum with students because of limited access and even in normal conditions they are often constrained due to limited equipment and practicum facilities. Virtual Labs is the best solution for doing "REAL TIME" practicum whenever and wherever students are.

The example below is one of the materials that teachers can use in practically practicing learning. The subject that is studied is about Pascal's Law. In this simulation, students can adjust the amount of pressure needed to lift a load in a cylinder with a large cross-sectional diameter, by adjusting the force exerted on a cylinder with a small cross-sectional diameter. In this way, students can experiment for real even though it is done virtually. 


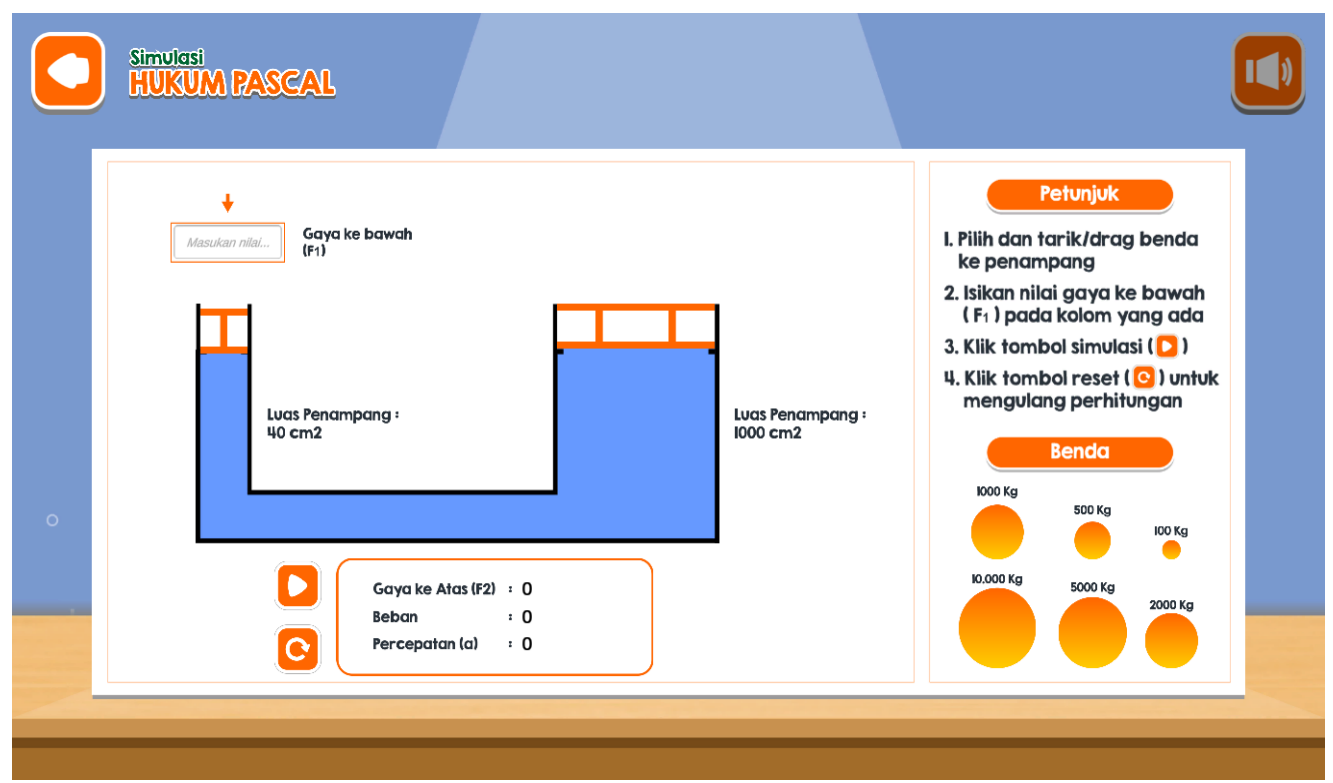

Figure 1. Display VIS-Lab for Pascal's Law practicum

The research results were divided into three parts, namely (1) the feasibility testing of science practicum learning with VIS-Lab, (2) the measurement of students' problem-solving skills and technological literacy in the experimental class and the control class, and (3) the results of the size effect of the VIS-Lab application on the escalation of the students' problem-solving skills and technological literacy.

The Practicality Test Results of Virtual Instruments System Laboratory (VIS-Lab)

The results of the VIS-Lab practicality test were carried out by giving questionnaires to the science teachers and the students. The responses from the teacher and students are combined which can be seen in Table 4 below.

Table 4. The results of the VIS-Lab practicality test from teachers and students

\begin{tabular}{lllcc}
\hline No & \multicolumn{1}{c}{ Validator } & \multicolumn{1}{c}{ Assessed Components } & $\begin{array}{c}\text { Scale } \\
\text { Value 5 }\end{array}$ & Category \\
\hline 2 & Evaluation of & Learning objectives & 3.4 & Good \\
& Science & Learning materials & 3.2 & Good \\
& Teachers & Linguistic Component & 4.6 & Very \\
& & & & Good \\
& \multirow{3}{*}{ Student } & Learning time & 3.4 & Good \\
& & Learning objectives & 3.2 & Good \\
& Learning materials & 3.1 & Good \\
& Linguistic Component & 3.3 & Good \\
& Learning time & 4.6 & Very \\
& & & Good \\
\hline
\end{tabular}


Based on the VIS-Lab practicality test results above, it can be seen that the application of VIS-Lab can be categorized as "good" and "very good". These results indicate that VIS-Lab is suitable to be used in the learning process. After getting the VISLab which is practical for the junior high school students in science practicum, the effectiveness of the model to enhance students' technological literacy and problemsolving skills was tested.

\section{The Test Results of the Effectiveness of VIS-Lab Application}

The field testing was conducted to determine the feasibility of the developed VIS-Lab learning media. In addition, it was also to reveal the results on the development of the students' technological literacy and problem-solving after the learning of momentum and impulse material. Meanwhile, the testing data on the students' technological literacy and problem-solving are presented in Tables 5 and 6 belo

.Table 5. Test Results of Students' Technological Literacy

\begin{tabular}{|l|l|c|c|c|c|c|}
\hline \multirow{2}{*}{ No } & \multicolumn{1}{|c|}{ Group } & \multirow{2}{*}{$\begin{array}{c}\text { Students } \\
\text { Number }\end{array}$} & \multicolumn{2}{c|}{$\begin{array}{c}\text { Average Technology } \\
\text { Literacy Ability }\end{array}$} & \multirow{2}{*}{$\begin{array}{c}\text { Average } \\
\text { Gain Value }\end{array}$} & Category \\
\cline { 5 - 7 } & & Pre test & Post- test & & \\
\hline 1 & Control & 34 & 25,616 & 61,173 & 0,461 & Moderate \\
\hline 2 & Experi-ment & & 42,788 & 76,778 & 0,558 & Moderate \\
\hline
\end{tabular}

Based on the results of the students' technological literacy test in Table 5, the data obtained in the form of $\mathrm{N}$-gain values in the control and experimental classes were 0.461 and 0.558 , respectively, with the medium category.

Table 6. Test Results of Students' Problem-Solving Skills

\begin{tabular}{|c|c|c|c|c|c|c|}
\hline \multirow[t]{2}{*}{ No } & \multirow{2}{*}{ Class } & \multirow{2}{*}{$\begin{array}{l}\text { Students } \\
\text { Number }\end{array}$} & \multicolumn{2}{|c|}{$\begin{array}{l}\text { Average Problem- } \\
\text { Solving skills }\end{array}$} & \multirow{2}{*}{$\begin{array}{c}\text { Average } \\
\text { Gain Value }\end{array}$} & \multirow[t]{2}{*}{ Category } \\
\hline & & & Pre-test & Post-test & & \\
\hline 1 & Control & \multirow{2}{*}{34} & 18,384 & 63,384 & 0,531 & Moderate \\
\hline 2 & Experiment & & 45,959 & 82,475 & 0,618 & Moderate \\
\hline
\end{tabular}

Based on the test results of the problemsolving skills above, the data obtained in the form of $\mathrm{N}$-gain value in the control and experimental classes were 0.531 and 0.618 , respectively, with the medium category. The influence of VIS-Lab learning media on Momentum and Impulse material was focused on students' technological literacy and problem-solving. To reveal these effects, a statistical test was performed with multivariate analysis or MANOVA. The data used for statistical tests of MANOVA were derived from the gain values both the students' technological literacy and problem-solving skills in the Momentum and Impulse material as the dependent variables. To perform the MANOVA test, the data must meet the test requirements, i.e. normality and homogeneity tests.

A normality test was done to find out whether the data from the experimental and the control class values were normally distributed. The results of Bivariate normality using the ShapiroWilk test classify if the Sig.value> 0.05 meaning that the data were normally distributed. The sig value for data in the experimental and control classes was more than 0.05 so it can be said that the data for both classes with dependent variables are normally distributed for the students' technological literacy problem-solving skills.

A homogeneity test was conducted to determine the similarity of the variance in both classes. The test was performed with Box's M statistical test with the assistance of SPSS software. Box's $M$ test data is considered homogeneous if Sig.value> 0.05 with the significance level of 5\% as presented in Table 7. 
Table 7. Test Results of Box's M

\begin{tabular}{lccccc}
\hline \multicolumn{1}{c}{ Variable } & Box's $M$ & $F$ & $d f 1$ & $d f 2$ & sig. \\
\hline Technological & 7,016 & 2,314 & 3 & 736270,00 & 0,079 \\
Literacy & 7,492 & 2,398 & 3 & 727360,00 & 0,064 \\
Problem Solving & &
\end{tabular}

Based on the Box's M test results, it was known that the Sig. values for the technological literacy and problem-solving variables were 0.079 and 0.064 , respectively, or more than 0.05 . So, it can be concluded that the two classes, the experimental and control classes, got the same variance or homogeneous.
The Manova test was done to find out whether there was a difference in the escalation of the students' technological literacy and problem-solving in both classes by using Hotelling's Trace test. The results of the test are presented in Table 8 below

Table 8. Test results of Hotteling's Trace

\begin{tabular}{ccccc}
\hline Variable & Class & sig. & $\begin{array}{c}\text { Partial Eta } \\
\text { Squared }\end{array}$ & Judgment \\
\hline Technological & Control & \multirow{2}{*}{0,000} & 0,021 & \\
Literacy & Experiment & & 0,090 & H0 is \\
Problem & Control & \multirow{2}{*}{0,000} & $\begin{array}{c}0,0473 \\
\text { rejected }\end{array}$ & \\
Solving & Experiment & & 0,365 & \\
\hline
\end{tabular}

Decision Criteria: sig. $<0,05$

Based on the results of the Hotelling's Trace test, the Sig. value of 0,000 was obtained for the technological literacy and problem-solving ability variable. These results indicate that Sig. value was less than 0.05 . So, it can be concluded that there were significant differences in the escalation of technological literacy and problem solving between the who learned using VIS-Lab learning media and realistic practicum learning.

Based on Table 8 above, the Partial Eta Squared values shows a large increase in the class with VISLab learning media compared to the realistic practicum classes in which the use of VIS-Lab learning media increased the technological literacy by $9.0 \%$ in the experimental class and $2.1 \%$ in the control class, respectively. Meanwhile, the effective contribution from the VIS-Lab learning media in the experimental class was $36.5 \%$ and the control class was $4.73 \%$. It shows that the use of VIS-Lab learning media contributes effectively to improving the ability of students' technological literacy and problemsolving.

The escalation of technology literacy is in line with the findings from Rice et al. (1999), where Deakin University students gave $75 \%$ positive responses to virtual laboratories and $93 \%$ of very supportive responses from the chemical engineering students (Rice et al. 1999 and Domingues et al. 2010). The experimental simulations were carried out in an autonomous model, so it had achieved a meaningful virtual laboratory learning by doing (Jian et al. 2005). By using a virtual lab, the material about mechanical waves becomes easier to understand, especially on basic techniques and concepts used in practicum (Jagodzinski \& Wolsky, 2015; Jiménez, 2003). Martinez-Jimenez et al. (2003) stated that many research results show the advantages of virtual labs as a tool for students in independent learning to prepare for activities in a real laboratory. This is corroborated by Jong's (2013) opinion which suggests that practicums that are carried out virtually will be more efficient than physical labs because it requires a shorter time with the right results instantly.

The escalation of problem-solving skills is also relevant to the findings from Huang (2004) which states that the virtual laboratory can improve concepts understanding and learning motivation. The virtual lab serves as a means to assist students in prelab preparation, strengthen students' concepts understanding, and as a substitute or complement to the real lab because students can repeat lab simulations that are still considered difficult (Hawkins \& Phelps, 2013; Tatli \& Ayas, 2010). The situations with certain problems can encourage students to find and analyze data. The result shows that the experiment with a virtual laboratory can be used anytime and anywhere effectively with fair cost. It can also deal with limited time and decrease experiment complexities and accident risks. 
Moreover, virtual laboratories can link and strengthen theories, enhance student enthusiasm for learning through interactivity, improve the ability to use Information and Technology (IT), and provide feedback (Chan 2009).

\section{CONCLUSION}

This research successfully applied VIS-Lab in the science learning of junior high schools. From the aspect of content validity, VIS-Lab is considered appropriate with the concepts of vibration, waves, and sound. Meanwhile, for the practicality aspect, this media is judged practical to be applied in the learning process according to the teachers and the students as the research respondents. These results indicate that VIS-Lab is suitable to be used in learning. The use of VIS-Lab learning media can enhance the students' technological literacy by $9.0 \%$ in the experimental class and $2.1 \%$ for the control class, respectively. The effective contribution of the VIS-Lab learning media was $36.5 \%$ for the experimental class and the control class was $4.73 \%$. It shows that the use of VIS-Lab learning media contributes effectively to improving the students' technological literacy and problem-solving.

\section{ACKNOWLEDGMENT}

We thank the Directorate of Research and Community Service, Directorate General of Higher Education for the fund support, and the management assistance during this research activity.

\section{REFERENCES}

Ahmed, M. E., \& Hasegawa, S. (2014). An Instructional Design Model and Criteria for Designing and Developing Online Virtual Labs, 4(3), 355-371.

Bautista, N.U. \& Boone, W.J. (2015). Exploring the Impact of TeachMETM Lab Virtual Classroom Teaching Simulation on Early Childhood Education Majors' SelfEfficacy Beliefs. Journal of Science Teacher Education, 26(3), 237262. Retrieved July 18, 2020 from https://www.learntechlib.org/p/1600 $\underline{05 /}$.

Chan, C (2009). Evaluating learning experiences in virtual laboratory training through student perceptions: acase study in Electrical and Electronic Engineering at the University of Hong Kong. Journal of the Higher Education Academy Engineering (2):10.
Supahar, Eko Widodo/ JSER 2021, 5(2), 41

Chi, M. T. H., \& Glaser, R. (1985). Problem solving ability. In R. J. Sternberg (Ed.), Human abilities: An informationprocessing approach (pp. 227-257). San Francisco, CA: W. H. Freeman \& Co.

Dyrberg, N. R., Treusch, A. H., \& Wiegand, C. (2017). Virtual laboratories in science education: Students' motivation and experiences in two tertiary biology courses. Journal of Biological Education, 51(4), 358-374.

Erstad, O. (2008). Trajectories of remixing digital literacies, media production and schooling. In C. Lankshear \& M. Knobel (Eds.), Digital literacies. Concepts, policies and practices (pp. 177-202). New York, NY: Peter Lang.

Funk, S., Kellner, D., \& Share, J. (2016). Critical media literacy as transformative pedagogy. In M.N. Yildiz \& J. Keengwe (Eds.), Handbook of research on media literacy in the digital age (pp. 1-30). Hershey, PA: Information Science Research. (17) (PDF) Toward a Multifaceted Heuristic of Digital Reading to Inform Assessment, Research, Practice, and Policy. Available from: https://www.researchgate.net/publication/ 339404897_Toward_a_Multifaceted_Heu ristic_of_Digital_Reading_to_Inform_Ass essment_Research_Practice_and_Policy [accessed Jul 18 2020].

Gilster, P. (1997), Digital literacy. New York: Wiley Computer Publications.

Foshay \& Kirkley. 2003 . Problem Solving.www.indiana-edu/m

Domingues, L., I., Rocha, F., Dourado, M., Alves, \& E.C., Ferreira (2010). Virtual laboratorios in (bio) chemical engineering education. Journal Education for Chemical Engineers. 5(10), 21-27.

Hawkins, I. \& Phelps, A. J. 2013. Virtual laboratory vs. traditional laboratory: which is more effective for teaching electrochemistry? Chemistry Education Research and Practice, 14, 516-523. DOI: 10.1039/c3rp00070b. 
Herga, N. R., Čagran, B., \& Dinevski, D. (2016). Virtual Laboratory in the Role of Dynamic Visualisation for Better Understanding of Chemistry in Primary School. Eurasia Journal of Mathematics, Science \& Technology Education, 12(3), 593-608.

Huang, C. 2004. Virtual labs: E-learning for tomorrow. PLoS Biology, 2(6), 734-735. DOI: 10.1371/journal.pbio.0020157.

Jagodzinsky, P. \& Wolski, R. 2015. Assesment of application technology of natural user interfaces in the creation of a virtual chemical laboratory. Journal Science Education and Technology, 24(1), 16-28. DOI: $10.1007 / \mathrm{s} 10956-014-9517-5$.

Jian, C.L. Du, A.H. Lee, C.W. Binns. (2005). Do dietary lycopene and other carotenoids protect against prostate cancer? Intertational Journal Cancer, 113 (6) (2005), pp. 1010-1014

Jiménez, P.M., Pedrajas, A.P., Polo, J., \& Bellido, M.S.C. 2003. Learning in chemistry with virtual laboratories. Journal of Chemical Education, 80(3), 346-352. DOI: $10.1021 / \mathrm{ed080p346.}$

Jong, Ton de., et al. 2013. Physical and virtual laboratories in science and engineering education. American Assocation for the Advancement of Science, 340(6130), 305308. DOI: $10.1126 /$ science. 1230579

Martin, A. (2006) "Literacies for age Digital Age" dalam Martin\&D. Madigan (eds)Digital Literacies for Learning. London. Facet.

Martinez-Jimenez, P., Pontes-Pedrajas, A., Polo, J. \& Climent-Bellido, M.S. (2003). Learning in Chemistry with Virtual Laboratories. Journal of Chemical Education, 80(3), 346. Retrieved July 18, 2020

from https://www.learntechlib.org/p/9504 $\underline{21}$

McGarr, Oliver. (2020) The use of virtual simulations in teacher education to develop pre-service teachers' behaviour and classroom management skills:
Supahar, Eko Widodo/ JSER 2021, 5(2), 42 implications for reflective practice, Journal of Education for Teaching, 46:2, 159169, DOI: $\underline{10.1080 / 02607476.2020 .17246}$ $\underline{54}$

Rice, M., O., David, C., Adrienne, S., Rod, O., Neville, \& H., Dale V-Lab: a virtual laboratory for teaching introductory concepts and methods of physical fitness and function. Australian Journal of Educational Technology 15(2).

Tatli, Z. \& Ayas, A. 2010. Virtual laboratory applications in chemistry education. Procedia Social and Behavioral Sciences, 9, 938-942. DOI: 10.1016/j.sbspro.2010.12.263.

Winkelmann, K., Keeney-Kennicutt, W., Fowler, D., \& Macik, M. (2017). Development, implementation, and assessment of general chemistry lab experiments performed in the virtual world of second life. Journal of Chemical Education, 94(7), 849-858. 